\title{
Acontia and mesentery nematocysts of the sea anemone Metridium senile (Linnaeus, 1761) (Cnidaria: Anthozoa)
}

\author{
CARINA ÖSTMAN ${ }^{1}$, JENS ROAT KULTIMA ${ }^{2}$, CARSTEN ROAT $^{3}$ \\ and KARL RUNDBLOM ${ }^{4}$ \\ ${ }^{1}$ Animal Development and Genetics, Evolutionary Biology Centre, Uppsala University, Norbyvägen 18A, SE-752 36 \\ Uppsala, Sweden, Carina.Ostman@ebc.uu.se \\ ${ }^{2}$ Uppsala University, Norbyvägen 18A, SE-752 36 Uppsala, Sweden. \\ ${ }^{3}$ Department of Ecology, Environment and Geology, Umeå University, Linneus väg 6, SE- 90187 Umeå, Sweden. \\ ${ }_{4}^{4}$ Uppsala University, Norbyvägen 14 A, SE-75236 Uppsala, Sweden.
}

\begin{abstract}
SUMMARY: Acontia and mesentery nematocysts of Metridium senile (Linnaeus, 1761) are described from interferencecontrast light micrographs (LMs) and scanning electron micrographs (SEMs). The acontia have 2 nematocyst categories grouped into small, medium and large size-classes, including 5 types: of these, large b-mastigophores and large p-amastigophores are the largest and most abundant. Mesenterial tissues, characterised by small p-mastigophores and medium p-amastigophores, have 3 nematocyst categories grouped as small and medium, including 6 types. Attention is given to nematocyst maturation, especially to the differentiation of the shaft into proximal and main regions as helical folding of the shaft wall proceeds. Groups of differentiating nematoblasts occur along acontia, and near the junction between acontia and mesenterial filaments. Nematoblasts are sparsely found throughout mesenterial tissues.
\end{abstract}

Keyword: cnidae, SEM, acontia, mesenterial filaments.

RESUMEN: Nematocistos acontia y mesentéricos de la anémona de mar Metridium Senile (Linnaeus, 1761) (CNidaria: AnthozoA). - Los acontios y los nematocistos de los mesenterios de Metridium senile (Linnaeus, 1761) se describen a partir de microfotografías de contraste-interferencia (LMs) y de microscopio electrónico de barrido (MEB). Los acontios tienen dos categorías de nematocistos agrupados en clases de talla, pequeños, medianos y grandes, incluyendo 5 tipos: de ellos, los mas grandes y abundantes son los b-mastigioforos grandes y los p-amastigióforos grandes. Los tejidos mesentéricos, caracterizados por pequeños p-mastigióporos y medianos p-amastigióforos, tienen 3 categorías de nematocistos agrupadas como pequeñas y medias, incluyendo 6 tipos. Se presta atención a la maduración de los nematocistos, especialmente a la diferenciación de los dardos en las regiones proximales y principales como plegamientos helicoidales de las paredes del dardo. A lo largo de acontia, y cerca de la unión entre los filamentos de acontia y filamentos mesentéricos aparecen grupos de nematoblastos en diferenciación. Los nematoblastos están escasamente representados en todos los tejidos mesentéricos.

Palabras clave: cnidoma, MEB, acontios, filamentos mesentéricos.

\section{INTRODUCTION}

Metridium senile (Linnaeus, 1761) is a common sub-tidal sea anemone on the Swedish west coast, growing on hard substrates (Wahl, 1985). Three species of sea anemones referred to the genus Metridium occur along the coasts of North America; M. senile, $M$. exilis (Hand, 1956) and M. farcimen (Brandt, 1835). Biochemical genetic studies corroborate morphological evidence that the European Metridium is best referred to the subspecies M. s. senile (Linnaeus) (Bucklin and Hedgecock, 1982; Fautin et al., 1990). In the present paper Scandinavian Metridium will be referred to $M$. senile (L.). 
Carlgren (1933, p. 22, Fig. 12) described Metridium dianthus Ellis (= M. senile) as a low-arctic-boreal form distributed in the North Sea. Several authors have regarded $M$. dianthus as conspecific with Metridium fimbriatum (Verrill, $1865=$ M. farcimen, Fautin and Hand, 2000) (Carlgren, 1933), but Carlgren (1933, 1934) did not regard the two nominal species as identical and reported differences in nematocyst size between $M$. dianthus on the Swedish west coast and the arctic $M$. fimbriatum. Taxonomic distinctions between $M$. senile and $M$. farcimen have been made according to their cnidae (Hand, 1956; Kramer and Francis, 2004).

Sea anemones attacked by a nudibranch contract, withdraw their tentacles and extrude acontia for defence (Edmunds et al., 1976). The nudibranch Aeolidia papillosa (Linnaeus, 1767) is the chief predator of the Swedish M. senile population (Wahl, 1985; Anthony and Svane, 1994). Acontia are long, thread-like structures filled with nematocysts. They arise from the free, thickened edge of complete mesenteries, the mesenteric filaments (Batham and Pantin, 1951; Fautin and Mariscal, 1991, p. 268, Fig. 1).

Several authors have described the cnidom of Metridium. Some used nematocyst categories and a terminology that differs from what is presented here. Carlgren (1929, 1933) used penicilli (= p-amastigophores) and spirulae (= b-mastigophores). Based on the cone-shaped invagination $(=\mathrm{V}$-notch) at end of the inverted shaft Carlgren (1940, pp. 4, 5) subdivided Weill's microbasic mastigophores (Weill, 1934) into p-mastigophores with $\mathrm{V}$-notch and b-mastigophores without V-notch. Further, Carlgren described the everted p-mastigophore shaft forming a distinct cone at its distal end, whereas in the b-mastigophores the junction between shaft and tubule was gradual.

According to Carlgren (1945) the genus Metridium has, in addition to spirocysts, 4 categories of nematocysts: basitrichs, microbasic b- and p-mastigophores, and amastigophores, with size differences in different parts of the anemone. The basitrichs and b-mastigophores were difficult to distinguish (Carlgren, 1940, pp. 52-54). The nematocyst's size in different anemone structures is regarded as important taxonomically (Fautin, 1988).

Hand (1956) thought that most basitrichs recorded in the literature were b-mastigophores. Westfall (1965) noted the similarity between basitrichs and microbasic b-mastigophores, though they differed in size. Each had a straight shaft with dense spines and a long, narrow tubule.

Not adopting the terminology of Weill (1934), Schmidt (1969, p. 295, Fig. 6) used the terms brhabdoids for b-mastigophores and p-rhabdoids for p-amastigophores (p. 303, Fig. 9b-f). The term "amastigophore" refers to lack of a long distal tubule atop the discharged shaft. However, p-amastigophores have a tiny distal tubule (Cutress, 1955; Schmidt, 1969). The shaft model of a p-rhabdoid (= p-amastigophore) showed the $\mathrm{V}$-notch with attached tiny tubule (Schmidt, 1969, p. 295, Fig. 5).
Cutress (1955, p. 123, Fig. 1) illustrated the inverted p-mastigophore shaft with a V-notch, folded within the inverted shaft back up to the capsule aperture. TEM observations on amastigophores (= p-amastigophores) from M. farcimen (see Westfall, 1965, p. 390, Fig. 10) showed the shaft not reaching the capsule apex. In addition to the V-notch and the short, looped tubule, Westfall (1965, p. 390, Fig. 9) characterised the undischarged capsule of these amastigophores by a cupshaped granular matrix. Weill (1934, p. 34, Fig. 17) also illustrated a cup-shaped capsular content in undischarged Metridium amastigophores.

The early development of nematoblasts, capsules, tubules and their inversion has been studied in numerous TEM investigations: Metridium by Westfall (1966); the anemone Haliplanella by Watson and Mariscal (1983, 1984a,b); and various sea anemones by Watson (1988). An interstitial cell develops into a cnidoblast (Slautterback and Fawcett, 1959). The capsule is formed first, followed by the external tubule formed outside the capsule (Slauterback, 1961; Westfall, 1966; Watson and Mariscal, 1984a,b). As the tubule inverts into the capsule, the Golgi complex and endoplasmic reticulum (ER) regress (Slautterback and Fawcett, 1959; Carré, 1972, 1980; Carré and Carré, 1973; Holstein, 1980, 1981; Watson and Mariscal, 1984a,b). Westfall (1966, p. 389, Fig. 9) described the external tubule with an internal pleated tubule from b-mastigophores of $M$. farcimen. The internal tubule becomes tightly folded as it develops (Skaer and Picken, 1965; Picken and Skaer, 1966; Carré, 1972, 1980; Carré and Carré, 1973; Skaer, 1973), and spines are formed inside the tubule (Westfall, 1966; Skaer, 1973; Holstein, 1980). Skaer and Picken (1965) and Picken and Skaer (1966) used the terms folds and pleats to describe the helices of the internal tubule.

Schmidt (1969, pp. 295, 302, Figs. 6, 9b-f) differentiated the inverted shaft of b-rhabdoids (= b-mastigophores) and p-rhabdoids (= p-amastigophores) of Metridium into two regions. He used the term "faltstuck" for the tight, helically folded proximal shaft containing sparse spines, and the term "hauptstuck" for the main shaft with spaced helices and dense spines.

The present study illustrates nematocysts from acontia and mesenteries by light photomicrographs (LMs) and scanning electron micrographs (SEMs), including maturing stages of the nematoblast, capsule, tubule and shaft. Especially, we focus on the structure and differentiation of the inverted shaft. Our findings are compared with those of Cutress (1955), Skaer and Picken (1965), Picken and Skaer (1966), Westfall (1966), Schmidt (1969) and Kramer and Francis (2004). Hopefully, our illustrations will facilitate identification of Metridium nematocysts stored in nudibranchs, especially immature ones, if stored in the cnidosacs, as reported by Greenwood and Mariscal (1984). 


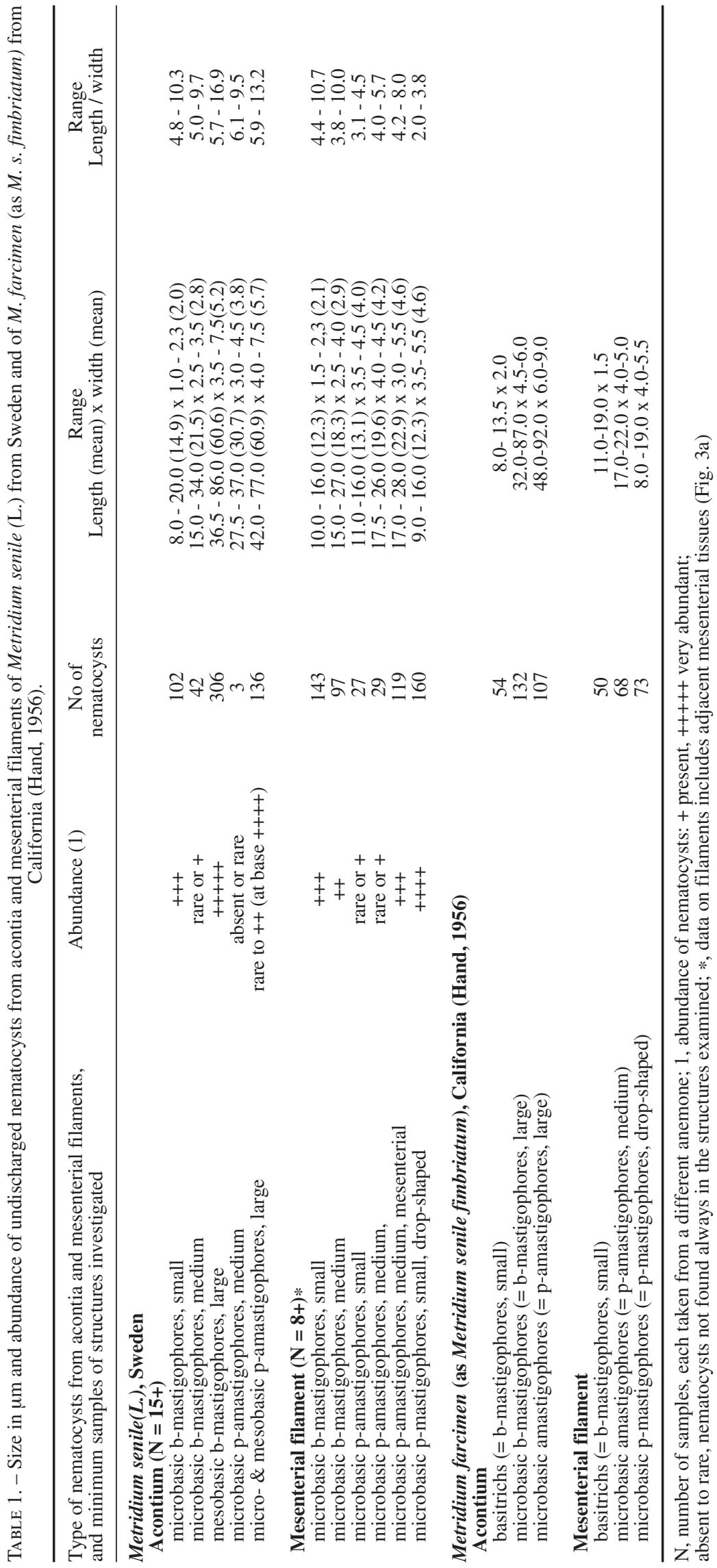

\section{MATERIALS AND METHODS}

Metridium senile were collected from the Gullmarsfjord on the Swedish west coast $\left(58^{\circ} 15^{\prime} \mathrm{N}, 11^{\circ} 28^{\prime} \mathrm{E}\right)$ in the period June to August 1996-2003. M. senile grew on hard substrates and appeared in two size-groups and several colour morphs (Anthony and Svane, 1994). Small red-brown individuals (pedal disc diameter (PDD) $<20 \mathrm{~mm}$ ) form mass aggregations in surface water down to $2 \mathrm{~m}$. Small to large, reddish to white individuals (PDD up to $45 \mathrm{~mm}$ ) grew solitary or in small presumed clones from the surface down to $c a .20 \mathrm{~m}$. Nematocyst samples, including all colour morphs and sizes, were taken from aggregated and solitary individuals. Anemones were examined soon after collection or after keeping in running seawater for a few days without feeding.

The size of acontia and mesentery nematocysts of $M$. senile and of M. farcimen (as M. s. fimbriatum) (see Hand, 1956) is shown in Table 1. Regression analysis were done on the undischarged capsule length from small (PDD ca 5 $\mathrm{mm}$ ) to large anemones (PDD ca 45 $\mathrm{mm})$ to determine whether the nematocyst size increased with increasing sea anemone size. The extended tentacle crown of undisturbed anemones was measured with a ruler to an accuracy of $5 \mathrm{~mm}$, and then related to the PDD. We consider it more accurate to measure the tentacle crown than the PDD, which could be bent around the substrate.

Squash preparations of living acontia and mesenteries for nematocyst studies in LM and SEM were made following the methods of Östman (1987) and Östman et al. (1991). To study detail structures in LM, some squash preparations were freeze-dried at $70^{\circ} \mathrm{C}$ for $24 \mathrm{~h}$. A Leica DMRBE light microscope equipped with interference-contrast optics, a 100x /1.30 PL, fluotar objective and a camera connected to a video recorder was used, and also a Philips XL 30 scanning electron microscope. LM measurements of the nematocysts were accurate to \pm 0.5 $\mu \mathrm{m}$. For each nematocyst type studied, at least 20 undischarged capsules were measured from each tissue of usually 5 or more individuals (Table 1). If possible, acontia and mesentery nematocysts were measured from the same specimens. The abundance was estimated by counting 
nematocysts in the field of view using the $100 \mathrm{x}$ objective or from the video screen. Some measurements were made on SEMs.

\section{RESULTS}

\section{Nomenclature and nematocysts studied}

Nematocysts were identified according to the classification system of Weill (1934) with modifications made by Carlgren (1940, 1945), Cutress (1955), Mariscal (1974), Calder (1977) and Östman (2000). The nematocyst nomenclature is that of Watson and Wood (1988) and Östman (2000).

Micro- and mesobasic b-mastigophores (Fig. 1cg) and p-amastigophores (Fig. 2) of acontia and microbasic p-mastigophores and p-amastigophores of mesenteries (Fig. 3) are described and illustrated. The b-mastigophores and p-mastigophores occurred in three size-classes; small, medium and large (Table 1). Medium p-amastigophores appeared in two morphs, of which one was found in the mesenteries only (Fig. $3 b-c)$. Nematocyst development is illustrated in Figure 4 , and the structure and differentiation of the shaft in Figures 5-7. The nematocysts were classified and characterised as follows:

1. Mesobasic b-mastigophores, large, capsule narrow elongate; occurring in acontia (Fig. 1c-e, Table 1); correspond to spirulae of Metridium dianthus Ellis (Carlgren, 1933), to microbasic mastigophores from Metridium senile (as Actinoloba dianthus) (see Weill, 1934, Fig. 44a,b), to microbasic b-mastigophores (Hand, 1956; Westfall, 1965, 1966) and to b-rhabdoids (Schmidt, 1969). Inverted shaft a distinct, thin rod, border between proximal and main shaft indistinct (Fig. 1d,e). Distal tubule in regular, slightly oblique, dense coils at right angle to capsule axis (Figs. 1d,e, 5a-c,e,f). Discharged shaft mesobasic, approximately twice capsule length, with three rows of large, densely-set spines (Östman et al., 2010, Fig. 3).

2. Microbasic b-mastigophores, small and medium, capsule narrow elongate (Table 1); from acontia (Fig. $1 \mathrm{e}-\mathrm{g}$ ) and mesenteries. Small microbasic b-mastigophores correspond to basitrichs of Carlgren (1945), Hand (1956) and Westfall (1965, 1966); medium bmastigophores correspond to b-mastigophores of the same authors. Discharged shaft microbasic, about one capsule-length (Fig. 1g).

3. Micro- and mesobasic p-amastigophores, small, medium and large, capsule elongate (Table 1); large ones from acontia (Figs. 2a,b, 6e), medium ones scarce in acontia (Fig. 2f-h), small and medium ones, mainly in mesenteries (Fig. 3b-e), correspond to microbasic amastigophores from $M$. senile (as A. dianthus) (see Weill 1934, pp. 34, 60, 149, Figs. 17, 53, 129-130), to amastigophores (Carlgren, 1945; Hand, 1956; Westfall, 1965, 1966; Kramer and Francis, 2004) and to p-rhabdoids (Schmidt, 1969). Inverted shaft broad, rod-shaped, proximal shaft and main shaft distinct;
V-shaped notch at end of main shaft (Figs. 3d,e, 6e). Microbasic and mesobasic p-amastigophores distinguished only by length of discharged shafts; microbasic shaft up to $1.5 \mathrm{x}$ capsule length (Fig. 2c,j), mesobasic shaft $1.5-2 \mathrm{x}$ capsule length (Fig. $2 \mathrm{a}, \mathrm{b}, \mathrm{g}, \mathrm{h}$ ). Tiny distal tubule inside capsule (Figs. 2i,j, 6e) or at everted shaft end (Fig. 2a,c). Heterotrichous shaft, with three rows of dense and sparse, long spines (Fig. 2c-e). Characteristic internal structure of capsular matrix in undischarged capsule (Figs. 3d,e, 6e,h), except in medium p-amastigophores, characteristic to mesenteries, here referred to as p-amastigophore, mesenterial (Fig. 3b,c).

4. Microbasic p-mastigophores, small, capsule drop-shaped; in mesenteries (Fig. 3b, Table 1); correspond to microbasic p-mastigophores of Carlgren (1945) and Hand (1955). Inverted shaft rod-shaped with V-shaped notch at distal end (Fig. 3b); shaft with long spines (Fig. 3g). Distal tubule, long, thin (Fig. 3g), usually not visible in undischarged capsule (Fig. 3f). No internal structure of capsular matrix.

\section{Acontia nematocysts}

In the heavily ciliated acontia (Fig. 1a,b) nematocysts were dense with their main axis transverse to the length of the acontium (Fig. 1d,e). Large mesobasic bmastigophores dominate (Fig. 1d,e, Table 1) and large microbasic and mesobasic p-amastigophores (Figs. $2 \mathrm{a}-\mathrm{c})$ were scattered among them together with mucus glands (Fig. 1e). Microbasic p-amastigophores (Fig. 2c) were far more common than the mesobasic ones (Fig. 2a,b). Small microbasic b-mastigophores (Fig. 1e-g), medium b-mastigophores and p-amastigophores (Fig. 2g,h) were also identified (Table 1).

In fully developed nematocysts the inverted shaft reached or slightly exceeded 3/4 of the capsule length (Fig. 1d). Some shafts were slightly undulating (Fig. $5 d)$. The inverted shaft of large b-mastigophores and p-amastigophores were differentiated into a proximal region with tight helices of the shaft wall and the remaining main shaft with spaced helices (Figs. 5c-e,g, 6e,h).

The broad p-amastigophore shaft enabled its end to invaginate and form the characteristic V-shaped notch (Figs. 3c-e, 6e). A tiny tubule was emerging from the notch and made one or two irregular coils towards the posterior capsule (Fig. 6e). The tubule was not always visible in undischarged capsules. After discharge the broad shaft-tubule abruptly narrowed to the tiny tubule (Fig. 2a,c), reaching $30 \mu \mathrm{m}$, or the tubule broke, and the shaft ended as a pointed cone (Fig. 2b,d, h,j). A few coils of the broken tubule were often seen inside discharged, flattened capsules (Fig. 2i,j). In freeze-dried preparations the tiny tubule appeared more distinct (Fig. 2j) than in wet preparations (Fig. 2f,i).

The discharged shaft and capsule remained swollen (Fig. 2a,b,g,h) until the internal capsular fluid had left. This took longer in mesobasic p-amastigophores than in microbasic p-amastigophores and mesobasic 

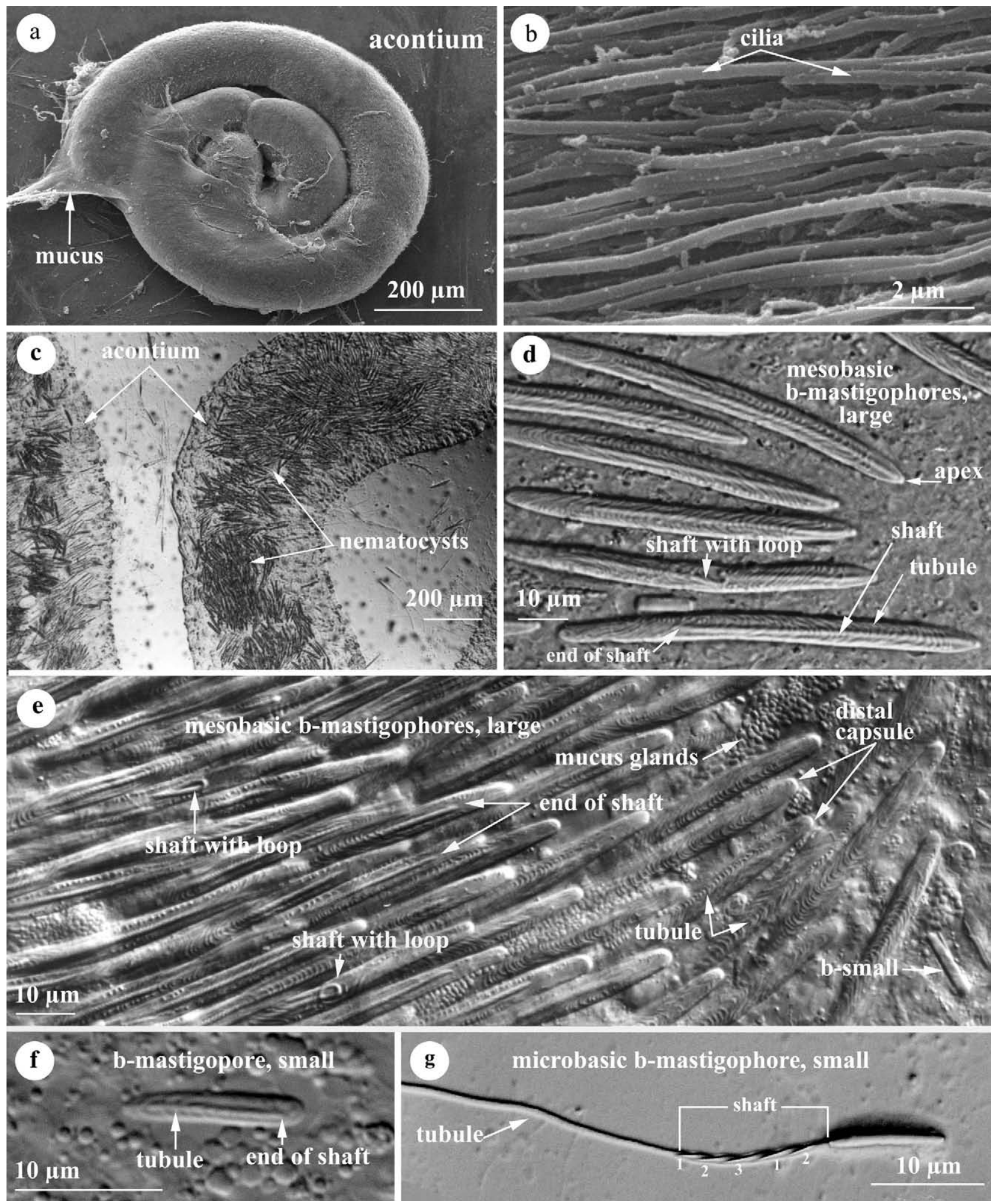

FIG. 1. - Acontia and acontia b-mastigophores. a) Part of an acontium partly covered with mucus (SEM). b) Surface of a) showing cilia (SEM). c) Parts of a compressed acontium showing nematocysts. d,e) Mesobasic b-mastigophores, large from acontium in c). d) Intact nematocysts to show shaft and tubule. e) Closely packed capsules in basal view. Note a small microbasic b-mastigophore at lower right. f,g) Microbasic b-mastigophores, small. g) Discharged. $b$-small, microbasic b-mastigophore, small; 1, 2, 3, three spine-rows. 

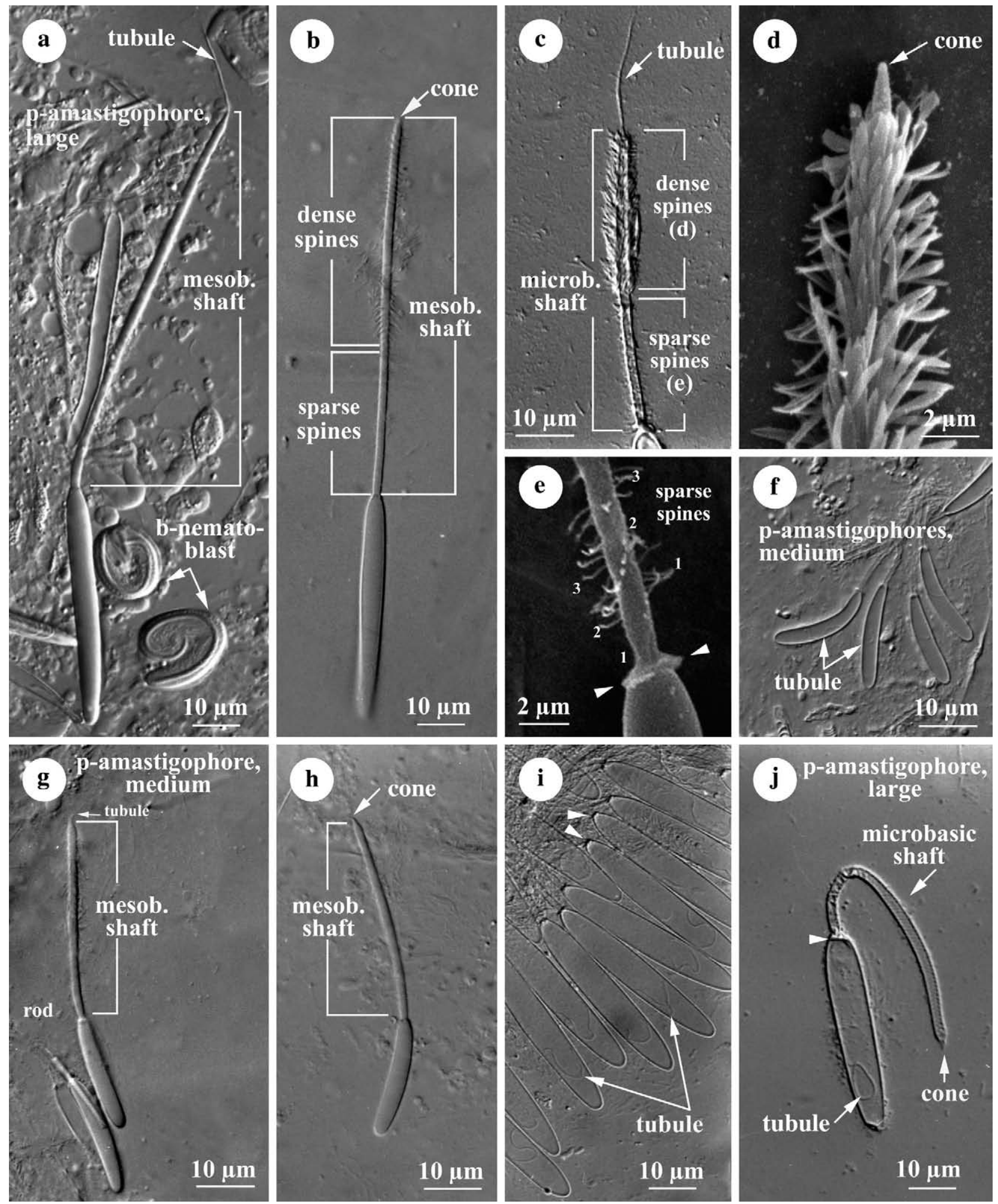

Fig. 2. - Acontia p-amastigophores, large and medium; discharged meso- and microbasics. a,b) Capsule and mesobasic shaft swollen with fluid. a) Shows tiny tubule at shaft end. Also two b-mastigophore nematoblasts with shaft- and tubule-coils inside folded capsule. b) Note dense spines on main shaft and sparse spines on proximal shaft. c) Microbasic shaft with tiny tubule and dense spines on main shaft. d) Distal main shaft with dense spines (upper region d in Figure c) and conical tip (SEM). e) Sparse spines on proximal shaft (lower region e in Figure c). Note flaps at capsule apex (arrow heads) (SEM). f) Microbasic p-amastigophores, medium, with tiny tubules inside discharged capsules. g,h) Mesobasic p-amastigophores, medium. g) Shaft with tiny tubule. Note rod at end of partly discharged shaft (lower left). h) Shaft with conical tip. i,j) Microbasic p-amastigophores, large. i) Discharged capsules, each with a tiny tubule inside. j) Conspicuous tubule in capsule (freeze-dried preparation). Arrow heads point at flaps at capsule apex; b-nematoblast, nematoblast of b-mastigophores; mesob., mesobasic; microb., microbasic; 1,2,3, three spine-rows. 

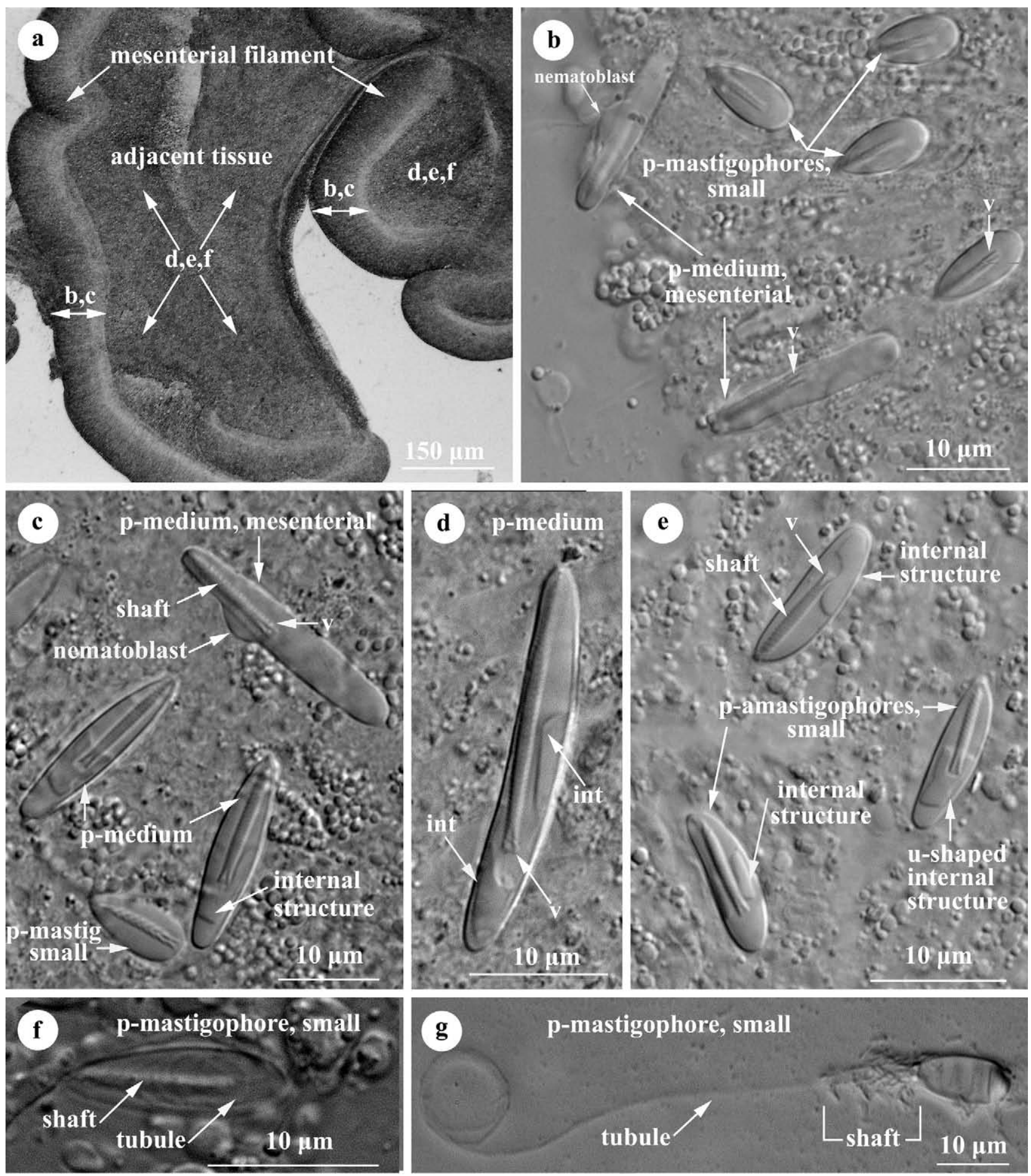

FIG. 3. - Mesentery p-mastigophores and p-amastigophores. a) Edge of mesentery showing filament and adjacent tissue. Arrows indicate zones of tissue for figures b,c (filament) and d,e,f (adjacent tissue). b) 4 p-mastigophores, drop-shaped, 2 p-amastigophores, medium, mesenterial. c) One p-mastigophore, drop-shaped (immature), 3 p-amastigophores, medium, one of mesenterial type; note its short shaft. d) A p-amastigophore, medium, with long shaft and conspicuous internal capsular matrix. e) 3 p-amastigophores, small, with irregular internal structure. f,g) p-mastigophores, drop-shaped. f) Tubule coiled within capsule. g) Discharged shaft and detached spines. int, internal structure; p-mastig, p-mastigophore; $p$-medium, p-amastigophore, medium; $v$, V-shaped notch at shaft end.

b-mastigophores. Swollen mesobasic p-amastigophore shaft were more conspicuous than flattened short shafts. Spines on the proximal shaft were sparse in spaced right-handed spine-rows (Fig. 2c,e). On the main shaft spines were dense in dense spine-rows (Fig. 2c,d). 

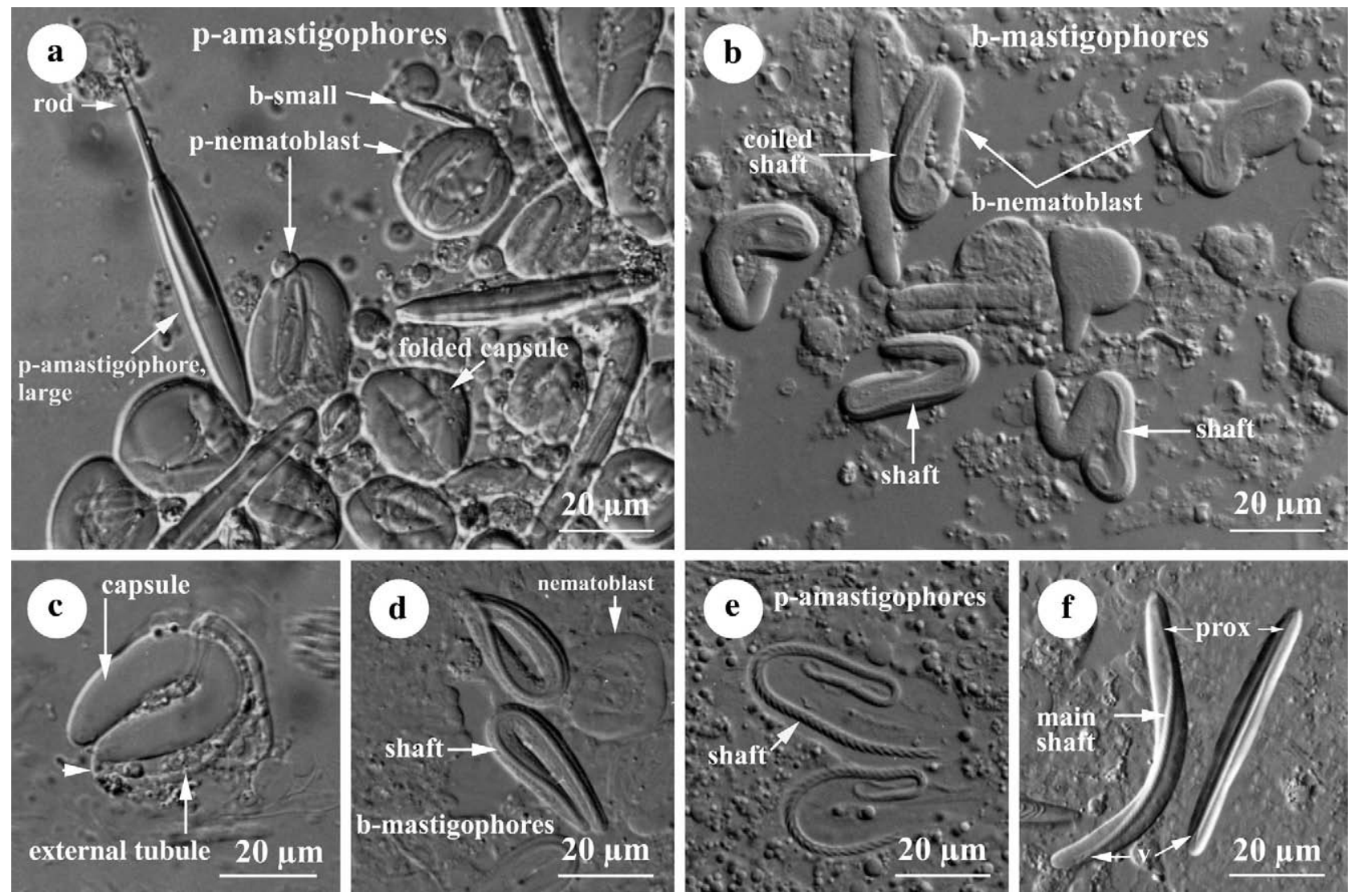

FIG. 4. - Differentiation in acontia nematocysts. a,c,e,f) p-amastigophores, large. b,d) b-mastigophores, large. a-c) Late nematoblasts from proliferation zones near acontium base. a) p-amastigophores. Note folded U-shaped capsule and external tubule. b) b-mastigophores, showing inverted shafts within folded capsules. c) p-amastigophore, showing connection between external tubule and U-shaped capsule (small arrow). d) b-mastigophores; U-shaped capsules and shafts, later than in b). Note capsule with external tubule. e,f) p-amastigophores showing differentiation of shaft. e) 2 late nematoblasts; folded shaft with spine pattern. f) Capsules immature but no longer U-shaped. Shaft differentiated in proximal (prox) and main shaft with helices and V-shaped notch at its end. $b$-nematoblast, nematoblast of b-mastigophore; $b$-small, b-mastigophores, small; p-nematoblast, nematoblast of p-mastigophore; prox, proximal shaft; $\mathrm{v}$, V-shaped notch at shaft end.

Regression analysis made on large b-mastigophores and p-amastigophores indicated a modest positive correlation between increasing capsule length and increasing anemone size $(\mathrm{p}<0.0001, \mathrm{R}-\mathrm{Sq}=0.29$ and $\mathrm{p}<0.001$, $\mathrm{R}-\mathrm{Sq}=0.087$, respectively).

\section{Mesentery nematocysts}

In the mesenterial filaments nematocysts were dense (Fig. 3a-c), and oriented with their capsule apex towards the filament margin (Fig. 3b). Small microbasic p-mastigophores with drop-shaped capsules dominated, followed by medium microbasic p-amastigophores, mesenterial (Fig. 3b,c, Table 1). The latter differed from the ordinary medium p-amastigophore (Fig. 3c,d) by its shorter inverted shaft, reaching $1 / 2$ to $1 / 3$ of the capsule length, by its broader, distal capsule and by lack of an internal structure of capsular matrix, characteristic for p-amastigophores (Fig. 3d). In addition, small and medium b-mastigophores and pamastigophores were sparsely scattered in the filament. In the adjacent tissue (Fig. 3a) nematocysts were sparse and small b-mastigophores were most abundant.
Drop-shaped p-mastigophores and medium pamastigophores, mesenterial, were characteristic for mesenteries. The narrow distal tubule of drop-shaped p-amastigophores (Fig. 3g) was vaguely seen coiled around the inverted shaft, if capsular fluid had left (Fig. 3f). The spines (Fig. 7k) were often detached from discharged shafts (Fig. 3g) and the distal tubule reached $225 \mu \mathrm{m}$. The distal tubule of the medium p-amastigophores, mesenterial, was vaguely seen making a coil towards the apical capsule (Fig. 7f,g). The discharged tubule (Fig. 7j) reached $30 \mu \mathrm{m}$.

\section{Acontia nematoblasts; formation of b-mastigophores and p-amastigophores}

Nematoblasts and immature nematocysts (Fig. 4) were most abundant within the acontia near their attachment site to the mesenterial filaments, but were also scattered along the acontia (Fig. 2a). Round nematoblasts with U-shaped capsule and external tubule already formed (Fig. 4a), and irregularly shaped nematoblasts enclosing broad folded capsules (Fig. 4b), were found among differentiating large b-mastigophores 

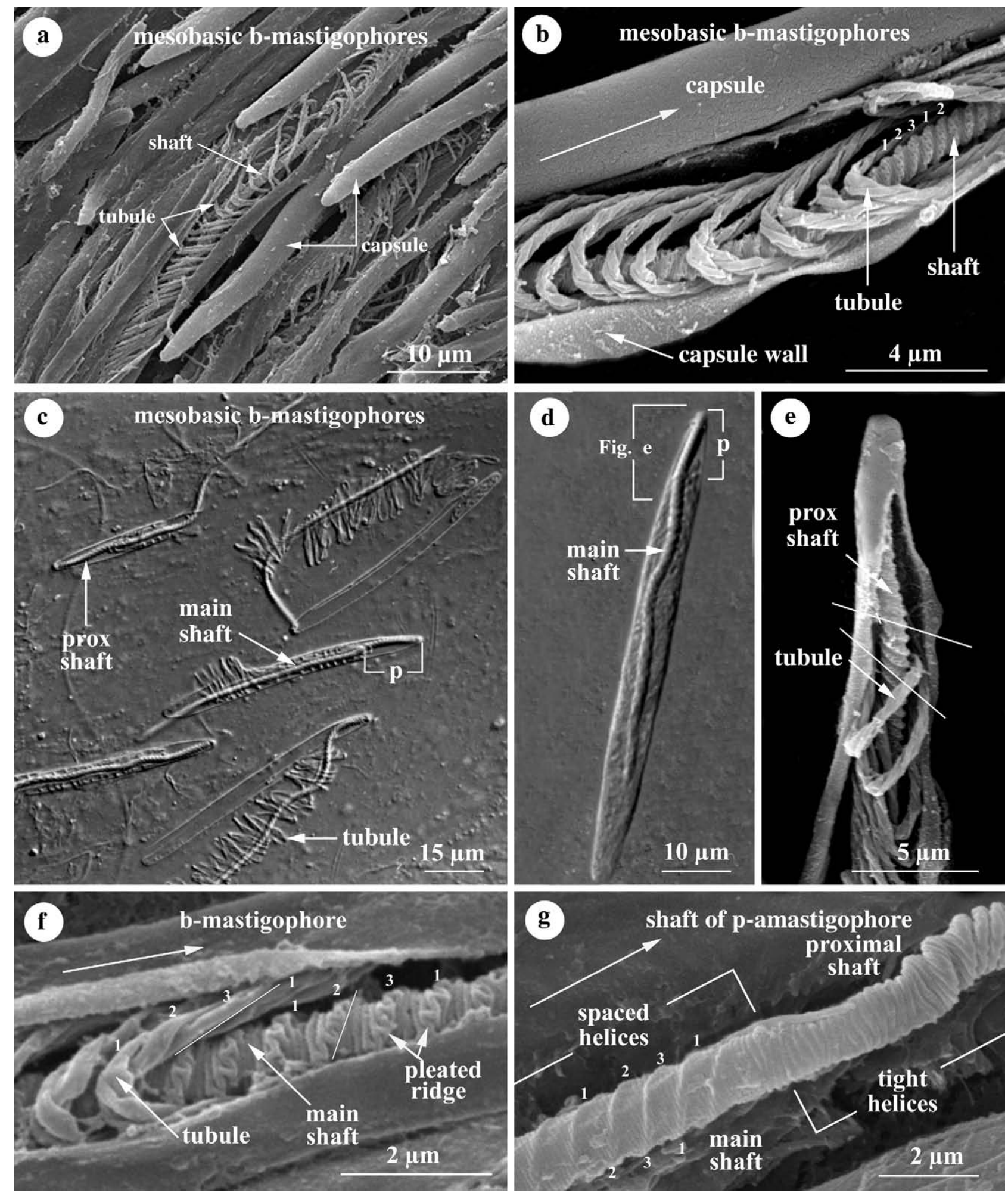

FIG. 5. - Intact and broken capsules of acontia nematocysts. a-f) Mesobasic b-mastigophores, large (as Fig. 1), and g) a p-amastigophore, large (as Fig. 2). a,b) Broken capsules showing shaft and tubule (SEM). b) Note helical folding of shaft and tubule. c) 4 broken capsules (1 intact). Their shafts and tubules have elongated without everting. Proximal shaft (p) straight. d) Intact capsule showing proximal and main shaft. e) Apical portion of a broken capsule (SEM). Helical folds of shaft wall appear to change pitch towards proximal shaft. f) Broken capsule showing helical folds on shaft and tubule walls (SEM). On the shaft these appear as pleated ridges. Lines show different pitches of shaft and tubule helices. g) Shaft of a p-amastigophore towards capsule apex (SEM). Proximal shaft with tight helices (has sparse spines), main shaft with spaced helices (has dense spines) (see Fig. 2c-e). Long arrows show direction of eversion; $p$, prox, proximal shaft; thin white lines show pitch of helices on shaft and tubule; $1,2,3$, correspond to the 3 spines-rows on everted shaft (b,f,g) and tubule (f). 

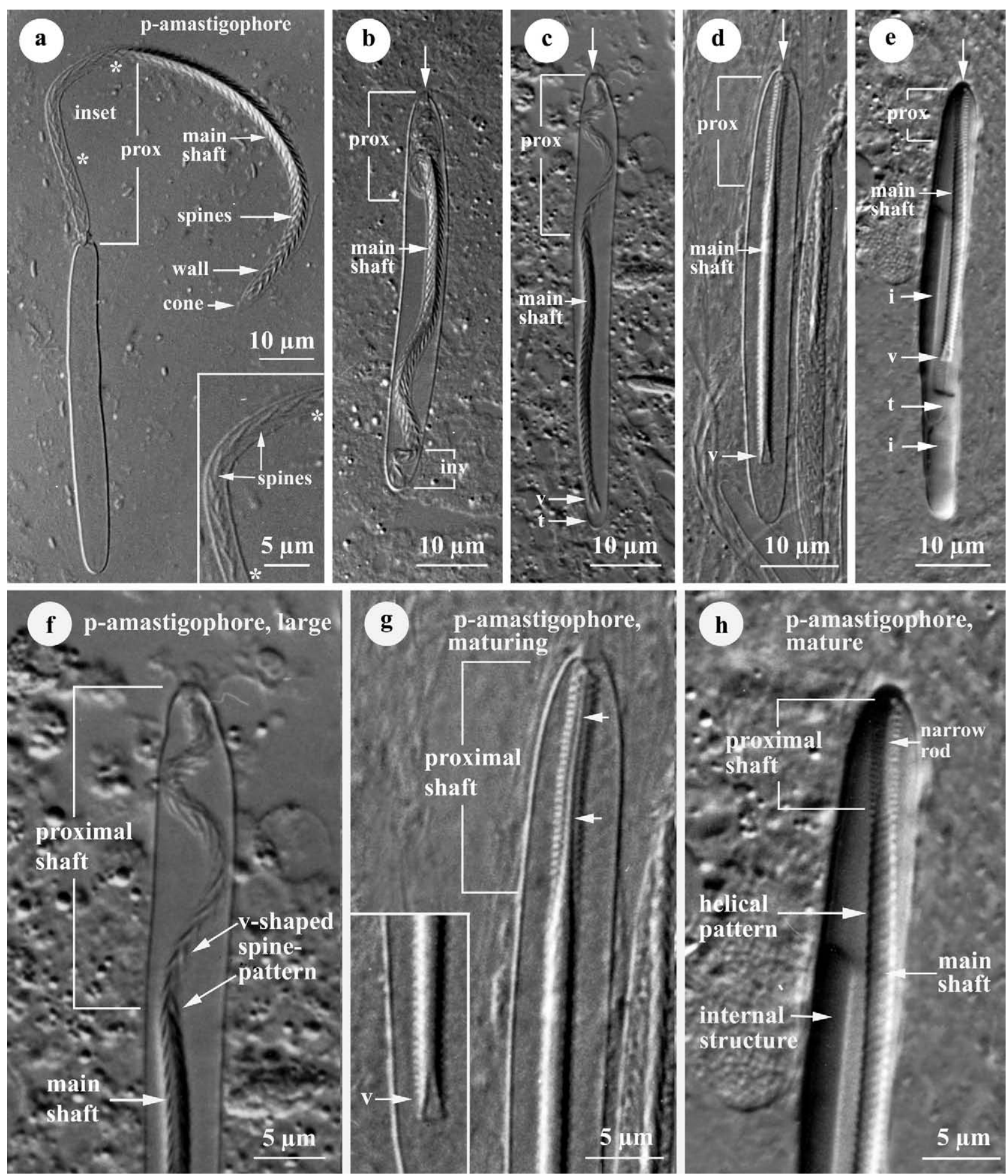

FIG. 6. - Acontia p-amastigophores, large. Inverted shaft differentiated into proximal and main regions. b-e) Illustrate differentiation of the shaft in capsules, interpreted as a time series. a) This empty capsule has ruptured (not seen) releasing the still inverted, elongated shaft. Spines on main shaft particularly clear. Inset) Enlargement of proximal shaft to shows spines (as Fig. 2e). b) Undischarged capsule, immature, with flexed shaft appearing longer than capsule. Proximal shaft strongly flexed, main shaft undulating. Spines on main shaft form clear V-pattern. Distal shaft flexed (marked inv) will later form the V-shaped notch. c,f) Immature capsule; shaft straightening, shorter, regions clear; V-pattern of spines still visible; distinct V-notch at shaft end. d,g) Immature capsule; shaft straight, slightly shorter. Note proximal shaft with dense helices or corrugations and thin rod along centre of proximal shaft (small arrows). Spines no longer visible. Dense helices around V-notch (g inset). e,h) A mature capsule; shaft fully shortened and rod-shaped. Boundary between regions of shaft indistinct; proximal shaft with tight helices or corrugations, narrow structure faintly visible. Main shaft with spaced helices. V-notch distinct. Arrows point at apical capsule end; small arrows point at thin rod; $i$, internal structure; prox, proximal shaft; $t$, tubule; $v$, V-shaped notch; * indicates area of inset. 
and p-amastigophores at later stages of development. We interpret the nematoblasts in Figures $2 a$ and $4 b$ as b-mastigophores and those in Figure 4a,c as p-amastigophores. Figure $4 \mathrm{c}$ shows the external tubule.

During maturation the broad, folded capsules evidently became narrow and U-shaped and later straightened to the shape of mature capsules (Fig. 4a-f). By then the external tubule had inverted, the shaft had grown distinct, and spines had formed. Shafts, early in differentiation, were seen within folded capsules (Fig. $4 \mathrm{~b}, \mathrm{e})$. They were longer than the capsules, flexed or coiled, and reached the distal capsule.

During the early stage of development the spines formed a V-shaped pattern pointing in the direction of eversion (Fig. 4e). As a nematocyst matured, the shaft apparently became gradually more pleated, its helices grew denser, and the shaft was shorter and straighter (Fig. 4f). The V-shaped spine pattern (Fig. 6b,c) was replaced by left-handed helices (Fig. 6e,h) and, in the $\mathrm{p}$-amastigophores, the characteristic $\mathrm{V}$-shaped notch was formed at the shaft end (Fig. 4f). In mature capsules the shaft was straight or slightly curved (Figs. 1d, 6e). Mature, undischarged p-amastigophores were recognised by their internal asymmetrical U-shaped structure of capsular matrix (Fig. 6e). This structure was not seen in immature p-amastigophores (Fig. 6bd) and in discharged or partly discharged capsules (Fig. 2a,b,g,h).

\section{Large mesobasic b-mastigophores; shaft and tubule}

In broken capsules of b-mastigophores the tubule coils around the shaft are shown (Fig. 5a-c). The border between the proximal shaft with dense helices and the main shaft with more spaced helices was indistinct in LM (Fig. 5c,d) and SEM (Fig. 5e). Differences in pitch between the helices on the proximal and main shaft are shown with white lines (Fig. 5e). The left-handed helices on the inverted shaft and tubule, formed by ridges and pleats, corresponded to the three spines-rows (Fig. $5 \mathrm{~b}, \mathrm{f}, 1,2,3)$. Additional small pleats and ridges were visible on the main ridges (Fig. 5f). The helices were more extended and the pleats or folds deeper on the distal tubule than those on the shaft (Fig. 5f). Differences in pitch between the helices on the shaft and on the distal tubule were large (Fig. 5f, white lines). Figure $5 \mathrm{c}$ shows broken capsules with still-inverted, extended, long shafts and enlarged tubule coils.

\section{Large p-amastigophores; differentiation of inverted shaft}

The inverted shaft, when viewed in SEM (Fig. $5 \mathrm{~g}$ ), was clearly separated into the proximal shaft with tight helices and the main shaft with spaced helices. In LM the two shaft regions were more obvious earlier in development (Fig. 6a-d) than in mature p-amastigophores (Fig. 6e,h).
Figure 6a shows the inverted shaft of an immature p-amastigophore extended outside a capsule, interpreted as ruptured. The V-shaped pattern of dense spines is clear on the main shaft, which ends abruptly in a small spineless cone. On the proximal shaft (Fig. 6a, prox) the $\mathrm{V}$-shaped pattern of sparse spines is seen in the inset.

Figure 6b-e is interpreted as a time series and illustrates the differentiation of the two shaft regions. Figure 6f,g,h shows enlargements of Figure 6c,d,e. Probably the inverted shafts in Figures $6 \mathrm{a}$ and $6 \mathrm{~b}$ are close to the same state of development. In Figure 6b the inverted, not yet helically pleated shaft reaches the capsule end. The shaft is coiled, flexed and undulating, and the two shaft-regions are shown. The V-shaped pattern is not discernable on the proximal coiled shaft (Fig. 6b, prox), but is distinct on the main shaft, except at its basal part (marked inv).

Figure 6c-e shows the increasing distance between shaft and distal capsule end as the nematocysts mature and the helically more-pleated shaft becomes shorter. The somewhat helically pleated shaft (Fig. 6c,f) is shorter and later in development then the shaft in Figure $6 \mathrm{~b}$. More capsular space is given to the undulating proximal shaft (Fig. 6c,f, prox), in which the V-shaped spine-pattern is distinct. The border between the proximal and main shaft is clear. On the nearly straight main shaft the V-pattern is partly replaced by helices. The Vshaped notch (Fig. 6c), formed by invagination of the shaft end (Fig. 6a,b, inv), is close to the distal capsule end. The tiny tubule is indistinct.

Figure 6d,g shows a p-amastigophore late in development with straight, shortened shaft. The V-shaped notch is on a clear distance from the distal capsule end. The border between the proximal and main shaft is distinct (Fig. 6g). Dense helices of the shaft wall are visible on the proximal straight shaft and around the V-notch (Fig. 6, inset). On the proximal shaft a narrow axial rod-shaped structure is seen, which broadens towards the main shaft.

Figure $6 \mathrm{e}, \mathrm{h}$ shows a mature $\mathrm{p}$-amastigophore with a shortened, straight shaft. The border between the proximal and main shaft is less obvious than earlier in development (Fig. 6c-d). The proximal shaft (Fig. $6 \mathrm{~h}$, prox) with tight helices has become shorter than the main shaft with wider-spaced helices. The narrow axial rod-shaped structure on the proximal shaft is indistinct. From the V-shaped notch the tiny tubule extends distally. The internal U-shaped matrix is partly discernable.

\section{Differentiation of mesentery nematocysts}

The mesentery nematocysts followed the same development (Fig. 7a-i) as large acontial p-amastigophores, except that in mature, small, drop-shaped p-mastigophores (Fig. 3b) and in p-amastigophores, mesenterial (Fig. 3b,c), no regular internal structure of a capsular matrix was visible, and their shaft was not 

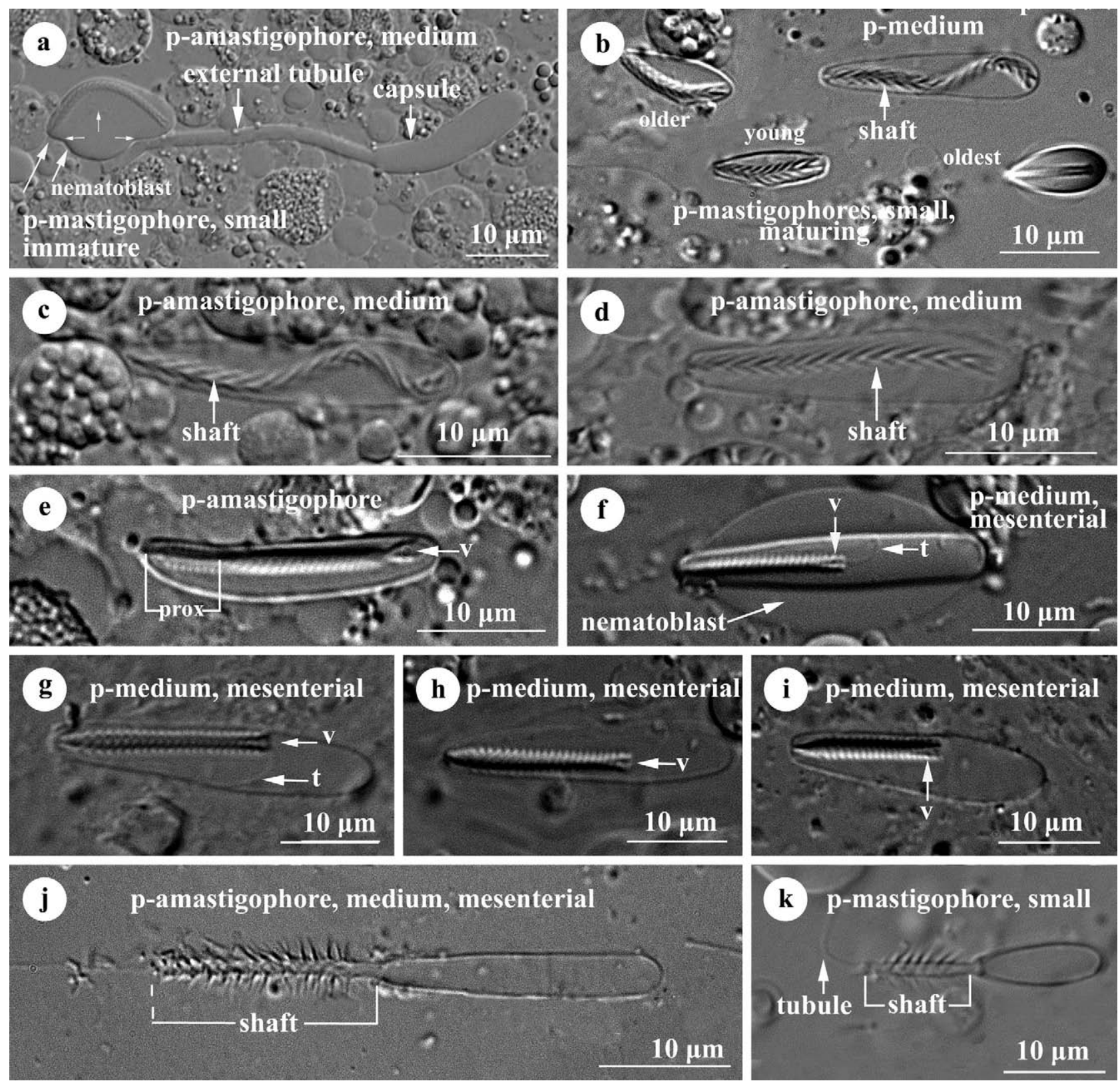

k p-mastigophore, small

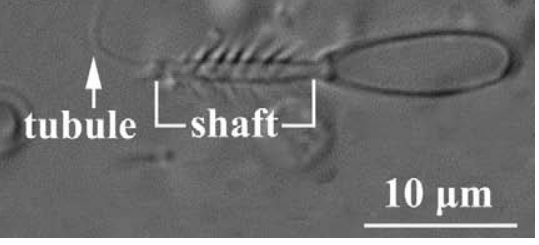

FIG. 7. - Stages in differentiation of mesentery p-amastigophores and p-mastigophores. a) To right a p-amastigophore, medium; early in development with external tubule. To left an immature p-mastigophore, small, drop-shaped, showing inverted shaft and nematoblast. Border between capsule and nematoblast faintly seen (tiny arrows). b) 3 p-mastigophores, small drop-shaped (most differentiate to right) and a pamastigophore, medium. Note V-shaped spine pattern. c,d) p-amastigophores, medium, showing V-shaped spine pattern. V-shaped notch at shaft end not developed. e) p-amastigophore, medium; proximal and main shaft distinct (see Fig. 6d). Proximal shaft with dense helices. Main shaft with spaced helices and V-notch. f,g,h.i) p-amastigophores, medium, mesenterial; late differentiation. The shaft shortens within capsule as its helices tighten. j) Discharged p-amastigophores, medium, mesenterial. Shaft end slightly damaged. k) Discharged p-mastigophore, small drop-shaped. p-medium, p-amastigophore medium; $t$, tubule; prox, proximal shaft; $v$, V-shaped notch.

differentiated into proximal and main regions. Nematoblasts and developing nematocysts were scattered in the tissue adjacent to the mesenterial filament (Fig. 7a-h). Figure 7a shows an extended external tubule in connection with a capsule (the nematoblast had probably ruptured). The same photograph shows an early developing small, drop-shaped p-mastigophore with $\mathrm{V}$-shaped spine pattern on its inverted shaft.
The V-shaped spine pattern in small drop-shaped p-mastigophores (Fig. 7b) and in medium p-amastigophores (Fig. 7b-d) was replaced by helices during later stages of development. Their shaft wall became more pleated, and their shaft shorter (Fig. 7b,e-i). The border between proximal shaft and main shaft was only seen in the ordinary p-amastigophores (Fig. 7e), and so was the narrow axial rod along the proximal shaft. 


\section{DISCUSSION}

\section{Late nematoblast to mature nematocyst; differentiation of the shaft}

Our broad U-shaped p-amastigophore capsule with external tubule (Fig. 4a,c) might be equivalent to the folded amastigophore capsule enclosing the external tubule (Westfall, 1966, p. 387, Figs. 6, 7). Westfall reported that spines were formed in the external tubule from its matrix (p. 389, Fig. 9). Our slightly swollen capsules and external tubules (Figs. 4c, 7a) had accordingly some internal contents, but like Skaer (1973) and Holstein (1980) we discerned spines only in the inverted shaft (Figs. 6b,c, 7b-d). In agreement with earlier statements (Slautterback and Fawcett, 1959; Carré, 1972, 1980; Carré and Carré, 1973), the nematoblast or cnidocyte, noted by us after the shaft and spines had started to differentiate, were mostly small (Fig. 3c) and apparently lacked content (Fig. 7f).

As mentioned above (Skaer and Picken, 1965; Picken and Skaer, 1966; Carré, 1972, 1980; Carré and Carré, 1973; Skaer, 1973), the tubule became more tightly folded after its arrival in the capsule. Our LM series of p-amastigophores (Fig. 6b-e) showed that the helical pleating process of the shaft continued late in differentiation. The shaft was noticeably shorter in mature nematocysts than early in shaft development, hence the gradually increasing distance between the Vshaped notch and distal capsule end during maturation (Fig. 6c-e)

Similar to Skaer and Picken (1965, pp. 139-141, plates 16-20), the pleats and ridges of the inverted shaft and tubule formed left-handed helices (our Fig. 5b,eg). Further, Skaer and Picken reported that the spines were attached to pockets in the folds of the shaft. The attachment sites of spines and spine-rows might correspond to the pleated ridges in our Figure $5 \mathrm{f}, \mathrm{g}$ marked $1,2,3$. The pitch of the helices increased as the diameter of the tubule diminished, as illustrated by Skaer and Picken (1965, p. 138, Fig. 3). On the narrow distal tubule (our Fig. 5f) the pitch-angles of the elongated helices were hence greater than those on the broad shaft. The pleated, undischarged tubule could expand some three times in length by smoothing the pleats when discharged (Picken and Skaer, 1966). In ruptured capsules (our Fig. 5c), resulting in the absence of capsular pressure, the inverted shafts and tubule coils were extended.

The difference in density and size of the spines explains the difference in the helical pattern on the inverted proximal shaft (= "faltstuck", Schmidt, 1969) and the main shaft (="hauptstuck", Schmidt, 1969), especially in the p-amastigophores (our Figs. 5g, 6e,h, $7 \mathrm{e}$ ). Shafts with small, spare spines (Fig. 2c,e) can be more tightly folded than shafts with long, densely-set spines (Fig. 2c,d). In mature nematocysts proximal shafts with dense helices (Fig. 6e,h) are thus more shortened (Fig. 6f-h) than the main shafts with wider- spaced helices (Fig. 6c-e).

Schmidt (1969, p. 293, Fig. 4a-c) showed the tiny tubule at the inverted shaft end before the invagination of the V-notch had started. The tiny tubule was only seen by us after the V-notch was shaped (Figs. 6c,e, $7 \mathrm{f}, \mathrm{g}$ ). We interpret that the cone-shaped shaft end (Fig. 6a) forms the V-notch as it invaginates into the short, flexed distal part of the main shaft (Fig. 6b, inv). After eversion the V-notch (Fig. 6c-e) is obviously equivalent to the cone at the end of the discharged shaft (Fig. $2 b, d, h, j)$.

The helices and folds around the V-notch (our Fig. $6 \mathrm{~g}$, inset) are denser than those on the remaining main shaft (see Schmidt, 1969, p. 295, Fig. 5). SEM pictures of a discharged p-amastigophore shaft of the sea anemone Sagartiogen viduatus (Östman et al., in preparation) showed that spines close to and on the distal cone were shorter than spines on the remaining main shaft.

The capsular U-shaped matrix in our mature pamastigophores (Fig. 3d) was certainly identical to the cup-shaped contents around the shaft in the undischarged amastigophore drawn by Weill $(1934$, p. 34, Fig. 17) and also to the cup-shaped mass of uniform granular matrix of amastigophores reported by Westfall (1965, p. 390, Fig. 9). Although irregular, the shape of the capsular matrix, from round U-shaped to square U-shaped, and with different length and thickness of the $\mathrm{U}$ (Fig. 3d, e, 6e), is a valuable characteristic in distinguishing mature p-amastigophores from $M$. senile and from S. viduatus (Östman et al., in preparation).

We assume that the capsular matrix is only visible in fully mature p-amastigophores. It is certainly ejected during discharge, since the structure was not visible in discharged and partly discharged capsules (Fig. 2a,b,g,h). Numerous undischarged large p-amastigophores without this regular internal structure were found in proliferation zones of the acontia (Fig. 4a), their shafts being noticeably longer (Figs. 4f, 6d) than the shafts in capsules with visible capsular matrix (Fig. $6 \mathrm{e})$. We have regarded these p-amastigophores as being in late development.

We had some doubts that the mesenterial p-amastigophores were immature p-amastigophores, ordinary type, since no characteristic capsular matrix was visible and they seldom discharged. However, due to their short inverted shaft, which only reached half the length of the capsule (Figs. 3b,c, 7i), we regarded them as mature and a variety of medium p-amastigophores. Moreover, the shaft was not differentiated into proximal and main regions (Fig. 7f-i), and when discharged the shaft armature seemed homotrichous and mostly the distal tubule was present (Fig. 7j).

The large amastigophore of Metridium senile pictured by Kramer and Francis (2004, p. 137, Fig. 4A) was certainly immature and close to the same age of development as our p-amastigophore (Fig. 6d). No capsular matrix was visible and the shaft was long. Its V-notch was closer to the distal capsule end than the V-notch in the amastigophore of M. farcimen (Kramer 
and Francis, 2004, p. 137, Fig. 4C), which we regard as mature, since part of the U-shaped capsular matrix was clearly visible.

The narrow axial rod-shaped structure in the inverted proximal shaft of p-amastigophores (Figs. 6d,g, 7e) seemed to be some kind of condensed capsular matrix. During eversion it formed the pointed rod at the end of the everting shaft (Figs. 2g, lower left, 4a, upper left) (see Östman et al., 2010). In the amastigophores of $M$. farcimen and M. senile (see Kramer and Francis, 2004, p. 137, Fig. 4A,C) this rod-shaped structure was also visible in the proximal shaft. As in our material (Fig. $6 \mathrm{e}, \mathrm{h})$ the rod-shaped structure was most conspicuous in immature nematocysts (Kramer and Francis, Fig. 4A, $\mathrm{C}, \mathrm{G})$.

In early development the b-mastigophore shaft was typically coiled inside the folded, irregularly shaped capsules (Fig. 4b). Many mature b-mastigophores with a coiled shaft remained undischarged (Fig. 1d,e); coiled shafts might prevent discharge. We were not able to distinguish b-mastigophores late in their development from mature ones.

\section{Nematocyst function and size}

Large acontial nematocysts may be particularly advantageous when the predation level is high (Kramer and Francis, 2004). We assume that large p-amastigophores are the most potent penetrating nematocysts of $M$. senile. Certainly their function is purely penetrating, since their coarse shaft is armed with long, densely-set spines, and its tiny distal tubule often remained in the discharged capsule. A long distal tubule might be used to entangle prey (see Östman and Hyman, 1997).

As mentioned (p. 486), the capsular fluid of the p-amastigophores does not leave the shaft at once after discharge, and stays longer inside the mesobasic p-amastigophore shafts (Fig. 2a,b) than in the shorter microbasic shafts (Fig. 2c,j). The internal hydrostatic pressure might be lower at the distal end of the mesobasic shaft, as it is spread over a longer distance than in the shorter microbasic shafts. The lower pressure may prolong the time for the fluid to open the cone at end of the discharge shaft (Fig. 2d). The hydrostatic pressure maintains the stiffness of the shaft until the fluid has left, and may increase the penetrating efficiency.

Small, drop-shaped microbasic p-mastigophores may be penetrators. The fluid stays for a long time in their discharged shaft, and the diameter differences between the broad shaft and the thin tubule may slow the internal fluid leaving the shaft.

The large b-mastigophores are the largest and most abundant acontia nematocysts in M. senile (Table 1). They certainly have a penetrating function since their shaft is armed with numerous large spines (Östman et al., 2010). The spines on their long distal tubules, however, are small and slender and not hook-shaped like those of penetrating isorhizas (Östman and Hydman, 1997; Östman, 2000). They are more similar to the spines on long distal tubules used to entangle prey (Östman and Hydman, 1999).

Some nematocyst types of $M$. farcimen are larger than corresponding nematocysts in $M$. senile (see Carlgren, 1933; Hand, 1956; Kramer and Francis, 2004), possibly because $M$. farcimen are larger than $M$. senile. A larger sea anemone might enable larger cells to produce larger cnidae (Francis, 2004). Regression analyses indicated (p. 490) that the large acontia nematocysts increased slightly in size with increasing sea anemone size (see also Kramer and Francis, 2004).

Interestingly, according to Carlgren (1933), Hand (1956) (our Table 1) and Francis (2004) the acontia amastigophores ( $=$ p-amastigophores), which solely has a penetrating function, are the largest nematocysts in M. farcimen. Large acontial nematocysts may be particularly advantageous if predation level is high (Kramer and Francis, 2004). In the anemone S. viduatus the acontia p-amastigophores are significantly larger than the acontia b-mastigophores and their abundance is higher than in M. senile (Östman et al., in preparation). The large size and abundance of the p-amastigophores in $S$. viduatus is perhaps related to the high predation by the nudibranchs Aeolidia glauca.

Hopefully, our detailed illustrations of mature and immature nematocysts will enable us to identify nematocysts stored in the cnidosacs of nudibranchs feeding upon M. senile.

\section{ACKNOWLEDGEMENTS}

The research was partly carried out in Fiskebäckskil at Kristineberg Marine Research station, Royal Swedish Academy of Science, and at Klubban Biological Station, University of Uppsala, Sweden. We express our gratitude to the directors and staff for providing laboratory facilities and specimens. The SEM work was performed in Uppsala at the Evolutionary Biology Centre, Uppsala University. Financial support was obtained from the faculty of Science of Uppsala University, Inez Johanssons Stiftelse, and from the Magnus Bergwalls Foundation and the O.E. and Edla Johansson Scientific Foundation, Stockholm. We thank Dr. Elaine Robson and Dr. Paul Cornelius for their critical and helpful reading of the manuscript and Dr. Daphne Fautin, as referee, for her invaluable assistance with the improvement of our manuscript.

\section{REFERENCES}

Anthony, K.R.N. and I. Svane. - 1994. Effects of flow-habitat on body size and reproductive patterns in the sea anemone Metridium senile in the Gullmarsfjord, Sweden. Mar. Ecol. Prog. Ser., 113: 275-269.

Batham, E.J. and C.F.A. Pantin. - 1951. The organization of muscular system of Metridium senile. Q. J. Microsc. Sci., 92: 27-54.

Bucklin, A. and D. Hedgecock. - 1982. Biochemical genetic evidence for a third species of Metridium (Coelenterata: Actiniaria). Mar. Biol., 66: 1-7.

Calder, D.R. - 1977. Nematocysts of the ephyra stages of Aurelia, Chrysaora, Cyanea, and Rhopilema (Cnidaria, Scyphozoa). Trans. Amer. Microscop. Soc., 96: 13-19. 
Carlgren, O. - 1929. Uber eine Actiniariengattung mit besonderen Fangtentakeln. Zool. Anz., 81: 109-113.

Carlgren, O. - 1933. The Godthaab Expedition 1928. Zoantharia and Actiniaria. Meddelelser om Grönland, 79(8): 1-55.

Carlgren, O. - 1934. Some actiniaria from Berings Sea and arctic waters. J. Washington Acad. Sci., 24(8): 348-353.

Carlgren, O. - 1940. A contribution to the knowledge of the structure and distribution of the cnidae in the Anthozoa. Acta Univ Lund (ser 2), 36(3): 1-62.

Carlgren, O. - 1945. Further contribution to the knowledge of the cnidom in the Anthozoa especially in the Actiniaria. Acta Univ. Lund (ser 2), 41(9): 1-24.

Carré, D. - 1972. Etude du development des cnidocystes dans le gastrozoide de Muggiaea kochi (Will, 1844) (Siphonophore calycophore). C. R. Acad. Sci. Paris, 275: 1263-1266.

Carré, D. - 1980. Hypothese sur la mechanisme de l'evagination du filament urticant des cnidocystes. Europ. J. Cell Biol., 20: 265-271.

Carré, C. and D. Carré. - 1973. Etude du cnidome et de la cnidogenese chez Apolemia uvaria (Lesueur, 1811) (Siphonophore Physonecte). Exptl. Cell Res., 81: 237-249.

Cutress, C.E. - 1955. An interpretation of the structure and distribution of cnidae in Anthozoa. Syst. Zool., 4: 120-137.

Edmunds, M., G.W. Potts, R.C. Swinfen and V.L. Waters. - 1976. Defensive behaviour of sea anemones in response to predation by the opistobranch mollusc Aeolidia papillosa (L). J. Mar. Biol. Ass. U. K., 56: 65-83.

Fautin, D.G. - 1988. Importance of nematocysts to actinian taxonomy. In: D.A. Hessinger and H.M. Lenhoff (eds.). The Biology of Nematocysts. pp. 487-500. Academic Press, San Diego.

Fautin, D.G. and C. Hand. - 2000. Metridium farcimen, the valid name of a common North Pacific sea anemone (Cnidaria: Actiniaria: Acontiaria). Proc. Biol. Soc., Washington, 113(4): 1151-1161.

Fautin, D.G., and R. Mariscal. - 1991. Chapter 6, Cnidaria: Anthozoa. In: F.W. Harrison and J.A. Westfall (eds), Microscopic Anatomy of Invertebrates. Placozoa, Porifera, Cnidaria, and Ctenophora, 2: 267-358.

Fautin, D.G., A. Bucklin and C. Hand. - 1990. Systematics of sea anemones belonging to genus Metridium (Coelentera: Actiniaria), with a description of M. giganteum new species. Wasmann J. Biol., 47(for 1989): 77-85.

Francis, L. - 2004. Microscaling: Why larger anemones have longer cnidae. Biol. Bull., 207: 116-129.

Greenwood, P.G. and R.N. Mariscal. - 1984. Immature nematocyst incorporation by the aeolid nudibranch Spurilla neapolitana. Mar. Biol., 80: 35-38.

Hand, C. - 1956. The sea anemones of central California part III The acontiarian anemones. Wasmann J. Biol., 13(2): 189-251.

Holstein, T. - 1980. An ultrastructural and kinematographic study of the nematocyst morphogenesis in selected coelenterate species. In P. Tardent and R. Tardent (eds.): Developmental and cellular Biology of Coelenterates, pp. 313-318. Elsevier/North Holland, Amsterdam.

Holstein, T. - 1981. The morphogenesis of nematocysts in Hydra and Forskålia: An ultrastructural study. J. Ultrastr. Res., 75: 276-290.

Kramer, A. and L. Francis. - 2004. Predation resistance and nematocyst scaling for Metridium senile and M. farcimen. Biol. Bull., 207: $130-140$.

Mariscal, R.N. - 1974. Nematocysts. In: L. Muscatine and H.M. Lenhoff (eds.), The Biology of Nematocysts, Coelenterate Biology, pp. 129-178. Academic Press, New York.

Östman, C. - 1987. New techniques and old problems in hydrozoans systematic. In: J. Bouillon, F. Boero, F. Cigogna and
P.F.S Cornelius (eds.), Modern trends in the Systematics, Ecology and Evolution of Hydroids and Hydromedusae, pp. 67-82. Clarendon Press, Oxford.

Östman, C. - 2000. A guideline to nematocyst nomenclature and classification, and some notes on the systematic value of nematocysts. Sci. Mar., 64(1): 31-46.

Östman, C., W.R. Kem and S. Pirano. - 1991. Nematocysts of the Mediterranean hydroid Halocordyle disticha. Hydrobiologia, 216/217: 607-613.

Östman, C. and J. Hydman. - 1997. Nematocyst analysis of Cyanea capillata and Cyanea lamarckii (Scyphozoa, Cnidaria). Sci. Mar., 61(3): 313-344

Östman, C., J. Roat Kultima and S.Y.G. Wong. - 2010. Dart formation in nematocysts of the sea anemone Metridium senile (Linnaeus, 1761) (Cnidaria: Anthozoa). Sci. Mar., 74: 499-510.

Picken, L.E.R. and R.J. Skaer. - 1966. A review of researches on nematocysts. In W.J. Rees (ed.): The Cnidaria and their evolution. Symp. Zool. Soc. Lond., 16: 19-50.

Schmidt, H. - 1969. Die Nesselkapseln der aktinien und ihre differentialdiagnostische bedeutung. Helgol. Wiss. Meeresunters., 19: $284-317$.

Skaer, R.J. - 1973. The secretion and development of nematocysts in a siphonophore. J. Cell Sci., 13: 371-393.

Skaer, R.J. and L.E.R. Picken. - 1965. The structure of the nematocyst thread and the geometry of discharge in Corinactis viridis Allman. Phil. Trans. R. Soc. Lond., 250: 131-164.

Slautterback, D.B. - 1961. Nematocyst development. In. H.M. Lenhoff and W.F. Lomis (eds.): The Biology of Hydra, pp. 77-130. Univ. of Miami Press, Coral Gables, Florida.

Slautterback, D.B. and D.W. Fawcett. - 1959. The development of the cnidoblasts of Hydra: an electron microscope study of cell differentiation. J. Biophys. Biochem. Cytol., 5: 441-452.

Wahl, M. - 1985. Metridium senile: dispersion and small scale colonization by the combined strategy of locomotion and asexual reproduction (lacertation). Mar. Ecol. Prog. Ser., 26: 271-277.

Watson, G.M. - 1988. Ultrastructure and cytochemistry of developing nematocysts. In: D.A. Hessinger and H.M. Lenhoff (eds.), The Biology of Nematocysts, pp. 143-164. London, Academic Press, San Diego.

Watson, G.M. and R.N. Mariscal. - 1983. Comparative ultrastructure of catch tentacles and feeding tentacles in the sea anemone Haliplanella. Tissue Cell., 15(6): 939-953.

Watson, G.M. and R.N. Mariscal. - 1984a. Calcium cytochemistry of nematocyst development in catch tentacles of the sea anemone Haliplanella luciae (Cnidaria: Anthozoa) and the molecular basis for tube inversion into the capsule. J. Ultrastruct. Res., 86: 202-214.

Watson, G.M. and R.N. Mariscal. - 1984b. Ultrastructure and sulfur cytochemistry of nematocyst development in catch tentacles of the sea anemone Haliplanella luciae (Cnidaria: Anthozoa). J. Ultrastruct. Res., 87: 159-171.

Watson, G.M. and R.L. Wood. - 1988. Colloquium on terminology. In: D.A. Hessinger and H.M. Lenhoff (eds.), The Biology of Nematocysts, pp. 21-23. London, Academic Press, San Diego.

Weill, R. - 1934. Contribution à l'étude des cnidaires et de leurs nématocystes. I, II. Trav. Stn. zool. Wimereux, 10-11: 1-701.

Westfall, J.A. - 1965. Nematocysts in the sea anemone Metridium. Amer. Zool., 5: 377-393.

Westfall, J.A. - 1966. The differentiation of nematocysts and associated structures in the Cnidaria. Z. Zellforsch., 75: 381-403.

Scient. ed.: P.J. López-González.

Received January 13, 2009. Accepted November 11, 2009.

Published online May 14, 2010. 